\title{
Relationship of the CD5 B Cell to Human Tonsillar Lymphocytes That Express Autoantibody-associated Cross-reactive Idiotypes
}

\author{
Thomas J. Kipps and Stuart F. Duffy \\ Department of Medicine, University of California, San Diego, La Jolla, California 92093-0945
}

\begin{abstract}
We examined human tonsillar B cells for expression of autoantibody heavy-chain or kappa light-chain cross-reactive idiotypes (CRIs), respectively defined by murine MAbs G6 or 17.109. We find 17.109 or $G 6$ each specifically binds a subpopulation of $B$ cells, respectively reacting with $3.8 \pm 3 \%$ (mean \pm SD) or $2.0 \pm 1.2 \%$ of all tonsillar lymphocytes. Cells reactive with both 17.109 and G6 comprise only $0.4 \pm 0.3 \%$ of tonsillar lymphocytes. Although each tested specimen had 17.109-positive cells, 2 of 19 tonsils (11\%) did not have any G6-reactive cells. We find that CRI-positive cells and CD5 B cells both co-express slgD but fail to bind peanut agglutinin or MAbs specific for CD10, indicating that both cell types reside in the mantle zones of secondary B cell follicles. However, less than half of the B cells bearing one or both of these CRIs express detectable levels of CD5. Nevertheless, we find that G6reactive lymphocytes constitute a multiclonal population of cells that express homologous heavy chain variable region genes, each rearranged to one of several distinct and apparently nonmutated $D$ and $J_{H}$ gene segments. Collectively, these studies indicate that expression of nondiversified autoantibody-encoding variable region genes may not be an exclusive property of $B$ cells that bear detectable levels of the CD5 surface antigen. (J. Clin. Invest. 1991. 87:2087-2096.) Key words: autoantibody $\bullet$ CD5 B cell $\bullet$ cross-reactive idiotype $\bullet V$ gene expression
\end{abstract}

\section{Introduction}

Malignant B cells from patients with chronic lymphocytic leukemia $(C L L)^{1}$ or small lymphocytic lymphoma (SLL) frequently express antibodies bearing cross-reactive idiotypes (CRIs) associated with IgM autoantibodies. In a study of over 30 CLL patients, one-fourth of the patients with kappa light chain-expressing leukemia cells had malignant lymphocytes that expressed a CRI defined by reactivity with a MAb, designated 17.109 (1). This antibody, prepared against an IgM rheu-

Address reprint requests to Dr. Kipps, Department of Medicine, University of California, San Diego, La Jolla, CA 92093-0945.

Received for publication 5 November 1990 and in revised form 4 February 1991

1. Abbreviations used in this paper: APC, allophycocyanin; $\mathrm{CD}$, cluster of differentiation antigen; CDR, complementarity determining region; CLL, chronic lymphocytic leukemia; CRI, cross-reactive idiotype; D, diversity; FR, antibody variable region framework; $J_{H}$, heavy-chain joining region; PCR, polymerase chain reaction; PE, phycoerythrin; PNA, peanut agglutinin; $R F$, rheumatoid factor; $V_{H}$ gene, heavy chain variable region gene; $V_{K}$ gene, kappa light chain variable region gene.

J. Clin. Invest.

(C) The American Society for Clinical Investigation, Inc. $0021-9738 / 91 / 06 / 2087 / 10 \quad \$ 2.00$

Volume 87, June 1991, 2087-2096 matoid factor (RF) recognizes a kappa light chain-associated CRI present on many IgM paraproteins with RF activity $(2,3)$. Furthermore, nearly one-fifth of all surface Ig-expressing CLL were found to react with G6 (4). This MAb is specific for an Ig heavy chain-associated CRI present on several RF paraproteins (5). Interestingly, nearly half of the CLL cases with leukemia cells reactive with 17.109 also reacted with G6, reflecting a biased co-expression of these CRIs $(4,6)$.

Evaluation of the molecular basis for these CRIs in CLL revealed that each is a serologic marker for expression of a conserved immunoglobulin V gene(s) with little or no somatic mutation. The 17.109-reactive neoplastic B cells from unrelated patients express nearly identical kappa light chain variable region genes $\left(V_{K}\right.$ genes) that belong to the $V_{K}$ IIIb sub-subgroup $(7,8)$. Finally, the sequences of the $V_{K}$ genes expressed by 17.109 -reactive leukemia cells share $>99 \%$ nucleic acid sequence homology with a germline $\mathrm{V}_{\mathbf{K}}$ III gene isolated from placental DNA, designated Humkv325 (9). Similarly, G6-reactive leukemia cells from unrelated patients express homologous heavy chain variable region genes $\left(V_{H}\right.$ genes) of the $V_{H} 1$ subgroup (10). Moreover, comparisons of the deduced amino acid sequences of G6-reactive CLL and that of G6-negative antibody heavy chains encoded by $V_{H} 1$ genes suggest that the G6-CRI in CLL is relatively resilient to substitutions within complementarity determining region 3 (CDR3), but affected by permutations within CDR1 and CDR2. Together these data argue that the G6-CRI in CLL is a serologic marker for a conserved $V_{H} 1$ gene also expressed with little or no somatic mutation.

Conceivably, the frequent expression of these autoantibody-associated CRIs in CLL or SLL may reflect the repertoire of the presumed normal cell counterpart to these malignancies, namely the cluster of differentiation antigen 5 (CD5) B cell. CD5 B cells constitute a small subpopulation of human B lymphocytes in lymphoid organs and peripheral blood of normal adults (11-15). These cells comprise the majority of B cells in the primary follicles of human fetal spleen $(16,17)$, where high proportions of cells express these CRIs (18). Finally, CD5 B lymphocytes have been reported to include nearly all the cells that spontaneously produce IgM autoantibodies $(19,20)$, including RF. As noted, IgM autoantibodies frequently bear the 17.109 CRI or the G6 CRI $(3,5,21)$. Also, IgM molecules co-expressing both CRIs almost invariably have RF activity (22). However, the relationship between CD5 B cells and nonmalignant $B$ cells that co-express autoantibody-associated CRIs has not been evaluated. Accordingly, we examined human tonsillar lymphocytes to determine the prevalence and surface antigen phenotype of the B cells that bear the 17.109 and/or the G6 CRI.

\section{Methods}

Patient materials. We obtained fresh residual lymphoid material from patients (ages 7-69, mean $26 \mathrm{yr}$ ) undergoing surgical tonsillectomy 
(Table I). Sections of each tonsil were frozen at $-70^{\circ} \mathrm{C}$ for immunohistochemical analyses as described $(4,23)$. A single-cell suspension was made from the remainder of each specimen. Mononuclear cells were isolated on density gradients of Ficoll-Hypaque, washed in Hanks' balanced salt solution and then suspended in FCS containing 10\% dimethylsufoxide (Sigma Chemical Co., St. Louis, MO), for storage in liquid nitrogen. Viability of recovered cells exceeded $90 \%$ before analyses.

Antibodies and fluorescence probes. $\mathrm{G} 6$, a murine $\mathrm{IgG}_{1}$ MAb reactive with a autoantibody heavy chain-associated CRI (5) was provided by Drs. Rizgar Mageed and Roy Jefferis (University of Birmingham, Birmingham, England). We obtained an $\mathrm{IgG}_{1}$ MAb specific for a $\mathrm{V}_{\mathbf{K}}$ IIIb subgroup determinant(s) (24), from Dr. George Abraham (University of Rochester, Rochester, NY). MAb 17.109 is as described (2). Fluorochrome-conjugated MAbs specific for CD10 (CALLA), and CD19 (Leu 12) were purchased from Becton-Dickinson Immunocytometry Systems, San Jose, CA. Hybridomas obtained from the American Type Culture Collection, Rockville, MD were OKT3, an $\mathrm{IgG}_{2}$ anti-CD3 (25), DA4-4, an IgG ${ }_{1}$ anti-human mu heavy chain (26), dTA4-1, an IgG ${ }_{3}$ anti-human delta heavy chain (27), and THB-5, an


man CD5 (29), was provided by Dr. Robert Fox (Scripps Clinic and Research Foundation, La Jolla, CA). Anti-human kappa or anti-human lambda MAb-producing hybridomas were as described $(1,7)$. Antibodies were purified from ascites via precipitation with ammonium sulfate and either absorption with quartenary aminoethyl (Pharmacia Fine Chemicals, Uppsala, Sweden) or Protein A Sepharose column chromatography (BioRad Laboratories, Richmond, CA). Purified antibodies were conjugated with either fluorescein isothiocyanate (FITC; Molecular Probes, Inc., Eugene, OR), normal human serum-biotin (Pierce Chemical Co., Rockford, IL), R-phycoerythrin (PE; Chromaprobe Immunological, Redwood City, CA), or allophycocyanin (APC;
Chromaprobe Immunological) as described (1). Biotinylated antibodies used to stain cells for three- or four-color immunofluorescence analyses were developed with Texas Red-avidin (Molecular Probes, Inc.). Fluorescein-conjugated peanut agglutinin (FITC-PNA) was obtained from Vector Laboratories, Inc., Burlingame, CA. With the exception of PE or APC-labeled MAbs, all reagents were spun at $100,000 \mathrm{~g}$ for 15 min before use.

Flow cytometric analyses. Three- and four-color flow cytometric analyses were performed using a FACScan (Becton, Dickinson \& Co., San Jose, CA) equipped with Consort30 (Hewlett-Packard Co., Palo Alto, CA) or a dual laser FACStar ${ }^{\text {plus }}$ (Becton Dickinson \& Co.) equipped with a MicroVAX computer (Digital Equipment Corp., Marlboro, MA), as described (30). The latter allowed for use of Electric Desk software (Dr. R. Hardy, Fox Chase Cancer Center, Philadelphia, PA). Unless otherwise indicated, cells were labeled with fluorochromeconjugated MAbs and reagents in staining medium consisting of biotin-deficient RPMI-1640 (Irvine Scientific, Santa Ana, CA), 3\% FCS (Gibco Laboratories, Grand Island, NY), and $50 \mathrm{mM}$ Hepes (Irvine Scientific), $\mathrm{pH}$ 7.6. Although viability of the analyzed cell populations generally exceeded $90 \%$, cells were stained also with propidium iodide $(1 \mu \mathrm{g} / \mathrm{ml})$ to allow us to discriminate between living and dead cells during FACScan analysis (30).

Isolation of G6-reactive cells. Tonsillar lymphocytes, $10^{8}$, from tonsil no. 7 (Table I), were incubated with FITC-conjugated G6 for $30 \mathrm{~min}$ at $4^{\circ} \mathrm{C}$, washed, and then incubated with $1.6 \times 10^{7}$ anti-mouse $\mathrm{IgG}$ magnetic microspheres (Dynabeads, Dynal, Inc., Oslo, Norway) for $1 \mathrm{~h}$ at $4^{\circ} \mathrm{C}$ with gentle agitation. FACscan analyses of the G6-labeled cell population before addition of the magnetic beads demonstrated $4.1 \%$ of the cells displayed bright green fluorescence when excited at $488 \mathrm{~nm}$ (Table I). Magnetic bead-bound cells were isolated by twice decanting the cell suspension in the presence of a strong magnetic field. FACScan

Table I. Lymphocyte Subpopulations in Human Tonsil

\begin{tabular}{|c|c|c|c|c|c|c|c|c|c|c|c|c|c|c|c|}
\hline Sample no. & Sex & Dx & Patient age & $\mathrm{CD} 3$ & CD5 & CD19 & CD5 B & IgM & IgD & $\mathbf{K}$ & $\mathbf{L}$ & 17.109 & VK3b & G6 & G6/17.109 \\
\hline & & & $y r$ & \multicolumn{12}{|c|}{$\%$} \\
\hline 1 & $\mathbf{M}$ & $\mathrm{CT}$ & 16 & 4 & 27 & 97 & 21 & 76 & 74 & 49 & 41 & 4.2 & 6.1 & 3.4 & 0.2 \\
\hline 2 & $\mathbf{F}$ & CT & 20 & 6 & 25 & 93 & 16 & 75 & 69 & 51 & 38 & 6.3 & 9.1 & 4.5 & 0.7 \\
\hline 3 & $\mathbf{M}$ & AT & 22 & 26 & 31 & 73 & 2 & 58 & 54 & 39 & 30 & 4.4 & 5.5 & 2.0 & 1.0 \\
\hline 4 & $\mathbf{F}$ & AT & 20 & 15 & 29 & 78 & 13 & 45 & 29 & 50 & 33 & 1.3 & 2.2 & 0.8 & 0.1 \\
\hline 5 & $F$ & AT & 7 & 39 & 44 & 64 & 3 & 59 & 42 & 40 & 30 & 4.0 & 4.3 & 1.5 & 0.5 \\
\hline 6 & $\mathbf{M}$ & $\mathrm{CT}$ & 41 & 22 & 29 & 77 & 6 & 55 & 45 & 44 & 31 & 5.1 & 5.5 & 2.5 & 0.2 \\
\hline 7 & $\mathbf{M}$ & CT & 32 & 19 & 50 & 74 & 31 & 54 & 50 & 44 & 31 & 5.1 & 7.8 & 4.1 & 0.8 \\
\hline 8 & $\mathbf{M}$ & OSA & 69 & 34 & 40 & 64 & 5 & 33 & 30 & 34 & 28 & 2.9 & 3.0 & 1.6 & 0.2 \\
\hline 9 & $\mathrm{~F}$ & AT & 19 & 49 & 55 & 45 & 10 & 24 & 19 & 20 & 19 & 3.3 & ND & 1.2 & 0.2 \\
\hline 10 & $\mathbf{M}$ & $\mathrm{CT}$ & 41 & 18 & 32 & 62 & 12 & 59 & 54 & 40 & 23 & 2.4 & 2.6 & 0.0 & 0.0 \\
\hline 11 & $\mathbf{M}$ & CT & 27 & 32 & 35 & 63 & 2 & 36 & 23 & 26 & 28 & 3.1 & ND & 2.2 & 0.2 \\
\hline 12 & $\mathrm{~F}$ & CT & 17 & 52 & 55 & 44 & 6 & 22 & 19 & 21 & 17 & 2.9 & 3.1 & 2.2 & 0.3 \\
\hline 13 & $\mathbf{M}$ & CT & 24 & 14 & 26 & 87 & 11 & 48 & 36 & 42 & 38 & 3.7 & ND & 2.0 & 0.5 \\
\hline 14 & $\mathbf{F}$ & AT & 4 & 13 & 36 & 77 & 26 & 62 & 59 & 40 & 39 & 4.6 & 5.8 & 1.8 & 0.3 \\
\hline 15 & $\mathbf{M}$ & CT & 30 & 19 & 28 & 77 & 12 & 64 & 59 & 44 & 35 & 3.4 & 5.9 & 3.4 & 0.3 \\
\hline 16 & $\mathbf{M}$ & OSA & 42 & 11 & 29 & 91 & 18 & 69 & 71 & 51 & 37 & 6.0 & ND & 0.0 & 0.0 \\
\hline 17 & $\mathbf{F}$ & CT & 21 & 27 & 47 & 71 & 17 & 48 & 45 & 40 & 30 & 2.6 & 5.6 & 2.3 & 0.2 \\
\hline 18 & $\mathbf{M}$ & AT & 14 & 4 & 40 & 97 & 36 & 83 & 83 & 62 & 31 & 4.3 & ND & 2.7 & 0.3 \\
\hline 19 & $\mathbf{M}$ & CT & 21 & 38 & 44 & 55 & 8 & 31 & 28 & 30 & 22 & 3.9 & 5.0 & 3.3 & 0.7 \\
\hline Average & & & 26 & 23 & 37 & 73 & 13 & 52 & 47 & 40 & 30 & 3.9 & 5.1 & 2.2 & 0.4 \\
\hline SD & & & 15 & 14 & 10 & 16 & 10 & 18 & 19 & 11 & 7 & 1.2 & 2.0 & 1.2 & 0.3 \\
\hline
\end{tabular}

In the column labeled "Dx" are the diagnoses underlying the medical indication for tonsillectomy: AT, acute tonsillitis (history < 6 mo); CT, chronic or recurrent tonsillitis; and OSA, obstructive sleep apnea. In the column labeled "patient age" are the ages of the patients from whom biopsy specimens were obtained. Values in remaining columns indicate the percentages of cells that have the surface antigen phenotype listed at the top of each column. Below each column are the mean percentages (average) and standard deviations of the mean (SD) of the values in each column. ND, not done. 
analysis demonstrated the decanted cell population did not contain any residual labeled cells. Cells adhering to the tube wall in the presence of the magnet were recovered, washed in RPMI-1640, and then used as the source of G6-positive cells. DNA was isolated from G6-positive cells as described $(8,10)$, except that subsequent to digestion with Proteinase- $\mathrm{K}$, the magnetic beads were removed from the preparation by $1-$ min centrifugation at $13,000 \mathrm{~g}$.

Polymerase chain reaction (PCR) amplification of genomic DNA. PCR was performed on $1 \mu \mathrm{g}$ of DNA isolated from G6-positive cells using Taq polymerase (31) (Cetus Corp., Emoryville, CA) and primers that correspond to the sense strand of a sequence common to the leader sequence of all $\mathrm{V}_{\mathrm{H}} 1$ genes [dGTTCHTCACCATGGACTGGACTG, $\mathrm{H}=\mathrm{A} / \mathrm{C} / \mathrm{T}]$ and to the anti-sense strand of a $\mathrm{J}_{\mathrm{H}}$ consensus [dCCTGAGGAGACMGTGACC, $\mathrm{M}=\mathrm{C} / \mathrm{T}$ ], as described (10). At the $5^{\prime}$ end of each primer, restriction sites for HindIII or EcoRI, respectively, were added to facilitate cloning of the amplified gene fragments. After 30 cycles of PCR, the amplified gene fragment was digested with EcoRI and HindIII, purified via agarose gel electrophoresis, and then cloned into a HindIII/EcoRI-digested pUC19 vector (Bluescribe, Stratagene, La Jolla, CA) for transformation into competent XL-1 Blue (Stratagene). Colonies containing plasmids with recombinant inserts were identified as described $(7,10)$. Plasmid DNA containing amplified recombinant insert DNA was isolated for double-stranded DNA sequencing as described (32). In addition, 1/20th of the PCR reaction mixture was analyzed by the method of Southern, as described (8). Oligonucleotide probes corresponding to the anti-sense of a sequence in the second complementarity determining region (G6-CDR2) [dGCGTAGTTTGCTGTACC] or to the anti-sense of a sequence in the second framework region $\left(\mathrm{V}_{\mathrm{H}} 1-\mathrm{FR}\right)$ [dCCATCCACTCAAGCCC] of the $V_{H} 1$ gene expressed by G6-reactive CLL (10) were used to probe the filter-immobilized DNA. Oligonucleotide synthesis, labeling, hybridization, and washing conditions were as described (1), with a final 1-min washing temperature of $49^{\circ} \mathrm{C}$. For DNA sequence analyses, we used the Genetics Computer Group Sequence Analysis Software Package on a VAX750 mainframe computer.

\section{Results}

Multiparameter flow cytometric analyses of tonsillar lymphocytes. We examined the lymphocytes from 19 tonsils using multiparameter flow cytometric analyses. Although most specimens were from young adults with acute or chronic tonsillitis, two surgical specimens (nos. 8 and 16 in Table I) were from patients with obstructive sleep apnea that required tonsillectomy to ameliorate partial upper airway obstruction. We could not discern any consistent phenotypic difference between these two and the other lymphocyte populations (Table I). The proportion of CD19-positive B cells ( $73 \pm 16 \%$; mean \pm standard deviation) generally exceeded the proportion of $\mathrm{CD} 3$-positive $\mathrm{T}$ cells $(23 \pm 14 \%)$ by twofold (Table I).

We readily detected CD5 B cells in each tonsil specimen (Table I). The proportion of CD5 B cells was calculated as the percentage of $B$ cells labeled with a fluorochrome-labeled antiCD5 MAb minus the background percentage $(<0.5 \%)$ of $\mathrm{B}$ cells stained with a fluorochrome-labeled anti-CD3 MAb of the same mouse Ig isotype. Similar to the variation noted in the proportions of B cells expressing CD5 in the peripheral blood of young healthy adults (15), the proportions of tonsillar lymphocytes that co-expressed CD5 and pan-B lymphocyte surface antigens ranged from $2 \%$ to $36 \%$ of the total lymphocytes or from $3 \%$ to $42 \%$ of the total B cells (Table I).

We examined tonsillar lymphocytes for reactivity with 17.109 or G6. With few exceptions, each tonsil contained a subpopulation of CRI-positive B cells that expressed the 17.109 and/or the G6 CRI (Table I). Cells bearing either CRI uniformly expressed B cell differentiation antigens CD19 and CD21 (data not shown). Lymphocytes that bound 17.109 comprised a subpopulation of B cells that expressed kappa light chain of the $\mathrm{V}_{\mathbf{K}}$ IIIb subgroup. The proportion of 17.109-positive cells ranged from $1.3 \%$ to $6.3 \%(m=3.9 \pm 1.2 \%)$ of the total lymphocytes, from $3 \%$ to $16 \%(m=10 \pm 3 \%)$ of the kappa light chain-bearing cells, and from $46 \%$ to $97 \%(m=77 \pm 16 \%)$ of the cells expressing kappa light chains of the $\mathrm{V}_{\mathrm{K}} \mathrm{IIIb}$ subgroup (Table I). Except in tonsil specimens from two individuals, G6-positive cells expressed either kappa or lambda light chains and comprised $0.1-4.5 \%(m=2.1 \pm 1.2 \%)$ of the total lymphocytes. Cells expressing both the 17.109 and G6 CRI comprised a very small subpopulation constituting $<0.1-1 \%(m=0.4 \pm 0.3 \%)$ of the total lymphocyte population (Table I). Tonsillar lymphocytes from two individuals (nos. 10 and 16 in Table I) did not possess any cells that expressed detectable levels of the G6-CRI (Table I). Immunohistochemical analysis of fresh frozen tissue sections of these two tonsil specimens confirmed that these tonsils lacked any G6-reactive lymphocytes (data not shown).

Four-color immunofluorescence analyses demonstrated that CRI-positive tonsillar lymphocytes share with tonsillar CD5 B cells the phenotype of mantle zone lymphocytes. Tonsillar B cells can be delineated into subpopulations based upon the differential expression of sIgD, CD10 and receptors for PNA (Fig. 1). Cells residing within the mantle zone bear sIgD and fail to bind PNA or MAbs specific for CD10 (CALLA), whereas $B$ cells within the germinal center generally lack substantial sIgD, express low levels of CD10 and avidly bind PNA (33-35). We find that $>95 \%$ of tonsillar B cells reactive with 17.109 and/or G6 express sIgD and fail to bind PNA or MAbs specific for CD10 (Fig. 1, top). CD21-positive B cells that bind anti-CD5 MAbs also have this phenotype (Fig. 1, middle). However, we note that the gated CD21-positive B cell populations fail to bind anti-CD3 MAbs of the same mouse Ig isotype (Fig. 1, bottom). These data indicate that tonsillar CD5 B cells reside in the same anatomic sites as do CRI-positive B cells, namely within the mantle zones encapsulating the germinal centers of secondary B cell follicles.

Despite sharing the phenotype of mantle zone B cells, CRIbearing lymphocytes, and CD5 B cells each appear to comprise independent but partially overlapping B cell subsets. First, the proportions of CD5 B cells within the specimens apparently do not correlate with the proportions of cells found to express either one or both of the two CRIs. For example, in specimen no. 3, MAbs 17.109 or G6 respectively reacted with $4.4 \%$ or $2.0 \%$ of the lymphocytes, whereas only $2 \%$ of this specimen's cells expressed both pan-B cell surface antigens and detectable levels of CD5 (Table I). In contrast, specimen no. 18 had a much greater proportion of CD5 B cells (36\%) than tonsil no. 3, but still had proportions of CRI-bearing cells that were comparable to that of specimen no. 3 (Table I). Secondly, over one half of the tonsillar B cells expressing 17.109 and/or G6 do not express detectable levels of the CD5 surface antigen. For example, cells staining with PE-17.109 display brighter green fluorescence when co-stained with FITC-anti-CD5 than with FITCanti-CD3 (Fig. 2). However, a large fraction of the anti-CD5 stained CRI-positive cells (dashed line, Fig. 3, left panel) have a green fluorescence intensity that is indistinguishable from that of CRI-positive cells stained with a control anti-CD3 MAb of the same mouse Ig isotype (solid line, Fig. 3, left panel). Less than half of the tonsillar B cells that express both the 17.109 



Figure 1. Probability distribution of tonsillar B lymphocytes electronically gated to depict only those cells staining positively with APC-conjugated anti-CD21. Contour plots describe the logarithmic red (ordinate) or green (abscissa) fluorescence intensity of cells stained with PE anti-CRI MAb G6 (top row), PE anti-CD5 (middle row), or PE anti-CD3 (bottom row) and FITC anti-IgD (left column), FITC-PNA (middle column), or FITC anti-CD10 (right column).

and G6 CRIs also do not express detectable levels of CD5 (Fig. 3 , right panel).

Analyses of $V_{H}$ genes rearranged in G6-reactive tonsillar lymphocytes. To examine the molecular basis for CRI expression in normal tonsil, we evaluated the $V_{H}$ genes rearranged in G6-reactive lymphocytes using the PCR. Approximately 4 $\times 10^{6}$ G6-reactive cells were isolated from tonsillar lymphocytes of tonsil no. 7 (Table I). Because all G6-reactive IgM proteins of known sequence have heavy chain variable regions of the $V_{H} 1$ subgroup $(10,36)$, we performed PCR on genomic DNA extracted from G6-positive cells using oligonucleotide primers designed to amplify any $V_{H} 1$ that had undergone Ig gene rearrangement with $\mathrm{DJ}_{\mathrm{H}}$ gene segments (10). Southern analyses of $1 / 20$ th of the reaction product indicated that such PCR generated fragments of $\sim 600$ bp that hybridized specifically with an oligonucleotide complementary to the second framework region of all known $V_{H} 1$ genes $\left(V_{H} 1-F R 2\right)(10)$ (data not shown). Furthermore, PCR of $1 \mu \mathrm{g}$ of DNA from G6-reactive tonsillar lymphocytes generated amounts of $V_{H} 1$ gene product comparable to that of PCR using $1 \mu \mathrm{g}$ of genomic DNA from G6-reactive CLL B cells (data not shown).

Nucleic acid sequence analyses of the cloned PCR products
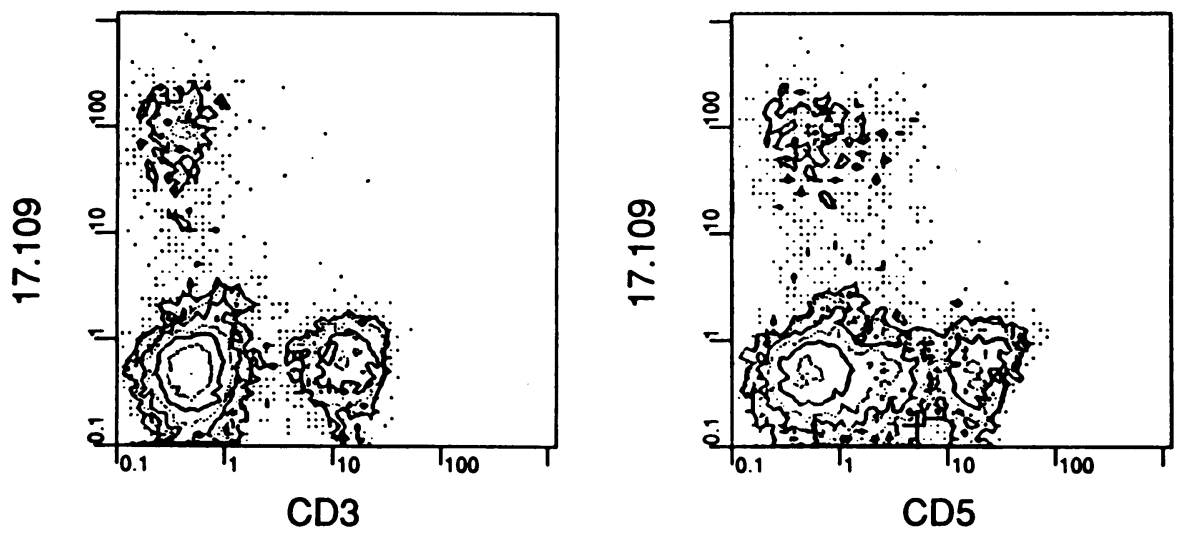

Figure 2. FACScan immunofluorescence analyses of tonsillar lymphocytes labeled with PE-conjugated 17.109 and fluorescein-conjugated anti-CD3 (left) or fluorescein-conjugated anti-CD5 (right). Numbers correspond to the relative red (ordinate) or green (abscissa) fluorescence intensity of the cells when excited at 488 nm. 




Figure 3. Relative green fluorescence intensity of tonsillar lymphocytes electronically gated to include only those cells staining positive for PEconjugated 17.109 (left) or PE-conjugated 17.109 and APC-conjugated G6 (right). Histograms correspond to the logarithmic green fluorescence intensity of such cells when co-stained with FITCconjugated anti-CD3 (solid line) or FITC-conjugated anti-CD5 (dashed line). reveal that G6-reactive tonsillar cells express homologous $V_{H} 1$ genes. Independent colonies of bacteria transformed with plasmids containing inserts derived from PCR of G6-reactive tonsillar lymphocyte DNA were screened by hybridization with oligonucleotide " $V_{H} 1-F R 2$ " or an oligonucleotide specific for the second CDR of $V_{H} 1$ genes found to encode the G6-CRI (G6-CDR2) (10). The DNA from all such colonies annealed with either oligonucleotide probe under conditions of high stringency (data not shown). 15 colonies were chosen at random for nucleic acid sequence analyses. All clones have $V_{H} 1$ genes that are highly homologous to that of L7, which in turn is identical with that of $a V_{H} 1$ gene expressed in G6-reactive CLL (10). The heterogeneity noted in the fifth base of each sequence reflects the sequence of the $V_{H} 1$ primer used to amplify the rearranged $V_{H}$ genes (Fig. 4). This primer has an $A / C / T$ wobble at this position. Except for clone L8, all clones contain functionally rearranged $V_{H} 1$ genes. The $V_{H}$ gene of $L 8$ is an apparent pseudogene. This $V_{H}$ gene has a single point deletion in the second base of codon 71 (Fig. 4) that produces downstream termination codons in the third framework and complementarity determining region (Figs. 4 and 5). All other clones have functional $V_{H} 1$ genes without stop codons or gene rearrangements that shift the reading frame of downstream gene segments.

Despite each clone having nearly identical $V_{H}$ regions, there is great diversity among the various clones in the third CDR (CDR3) and fourth framework regions. These regions are encoded by the $D$ and $J_{H}$ gene segments, that undergo recombination and amino-terminal nucleic acid base insertion immediately before $V_{H}$ gene rearrangement $(42,43)$. As such, the sequence of the CDR3 generally is idiosyncratic to each Ig V gene rearrangement. Only two clones, L17 and L37, share identity in the deduced CDR 3 region, indicating that these two variable region genes most likely were derived from the same B cell clone (Fig. 5). All other clones have highly distinctive sequences in the deduced CDR3 region, indicating that each was derived from an independent Ig V gene rearrangement (Fig. 5). Most clones have a segment within CDR3 that has a high degree of sequence homology with a known germline $\mathrm{D}$ minigene (37-41) (Fig. 5). Of the 14 distinct clones analyzed, at least 11 different germline $\mathrm{D}$ segments may be represented. In the region presumably encoded by a rearranged $\mathrm{J}_{\mathrm{H}}$ gene segment, nearly half $(6 / 13)$ of the 13 distinct and apparently functional clones use $\mathrm{J}_{\mathrm{H}} 4(\mathrm{~L} 17 / 37, \mathrm{~L} 25, \mathrm{~L} 34, \mathrm{~L} 36, \mathrm{~L} 39$, and L41), three use $\mathrm{J}_{\mathrm{H}} 5$ (L22, L26, L42), four use $\mathrm{J}_{\mathrm{H}} 6$ (L7, L26, L30, and L33) (Fig. 5). The $\mathrm{V}_{\mathrm{H}} 1$ pseudogene, $\mathrm{L8}$, apparently is juxtaposed with $J_{H} 1$. In addition to the variety noted in the $D$ and $J_{H}$ gene segments, the lengths of the regions presumably encoded by the $\mathrm{DJ}_{\mathrm{H}}$ gene segments varies greatly among the various clones, ranging from 18 codons for the shortest (L26) to 38 codons for L30 (Fig. 5).

\section{Discussion}

This study examines the relationship between CD5 B cells and tonsillar lymphocytes that express major autoantibody-associated CRIs respectively defined by MAbs 17.109 or G6. The former constitute a significant subpopulation of $B$ cells that readily is identified in each tonsil population (Table I). The latter define significantly smaller proportions of $B$ cells, and for G6-CRI-expressing cells, are not represented in all tonsils examined. Both populations have surface antigen phenotypes of mantle zone lymphocytes. Although originally claimed to reside in the germinal centers of human tonsil (11), tonsillar B cells expressing CD5 subsequently were noted to express low levels of Leu 16 (CD20) using multiparameter flow cytometric analyses (34). In addition, we note that both tonsillar CD5 B cells and CRI-positive $B$ cells express surface IgD and lack detectable binding affinity for anti-CD10 MAbs and PNA. These phenotypic characteristics distinguish $B$ cells located in the mantle zone from lymphocytes residing within the germinal center $(34,35)$. As such, these studies indicate that CD5 B cells reside in the same anatomic location as do cells bearing the 17.109 or G6 CRI.

However, not all CRI-bearing B cells are "CD5-positive" B cells. Despite sensitive immunofluorescence techniques, we find that less than half of the B cells bearing the 17.109-CRI or the G6-CRI express detectable levels of CD5. This also is true for B lymphocytes co-expressing both CRIs. As indicated by studies on isolated IgM paraproteins (22), such 17.109 and G6 reactive cells have a high probability of bearing sIg with RF activity. This suggests that RF-bearing B cells may not express detectable levels of CD5.

Conceivably, CD5-negative CRI-bearing B cells may have differentiated from CD5 B cells. A recent study indicated that human CD5 B cells may "differentiate" and thereby loose surface expression of $\mathrm{CD} 5$ upon in vitro culture with interleukins (ILs), IL-1 and IL-2 (44). Concomitant with the loss of CD5, 


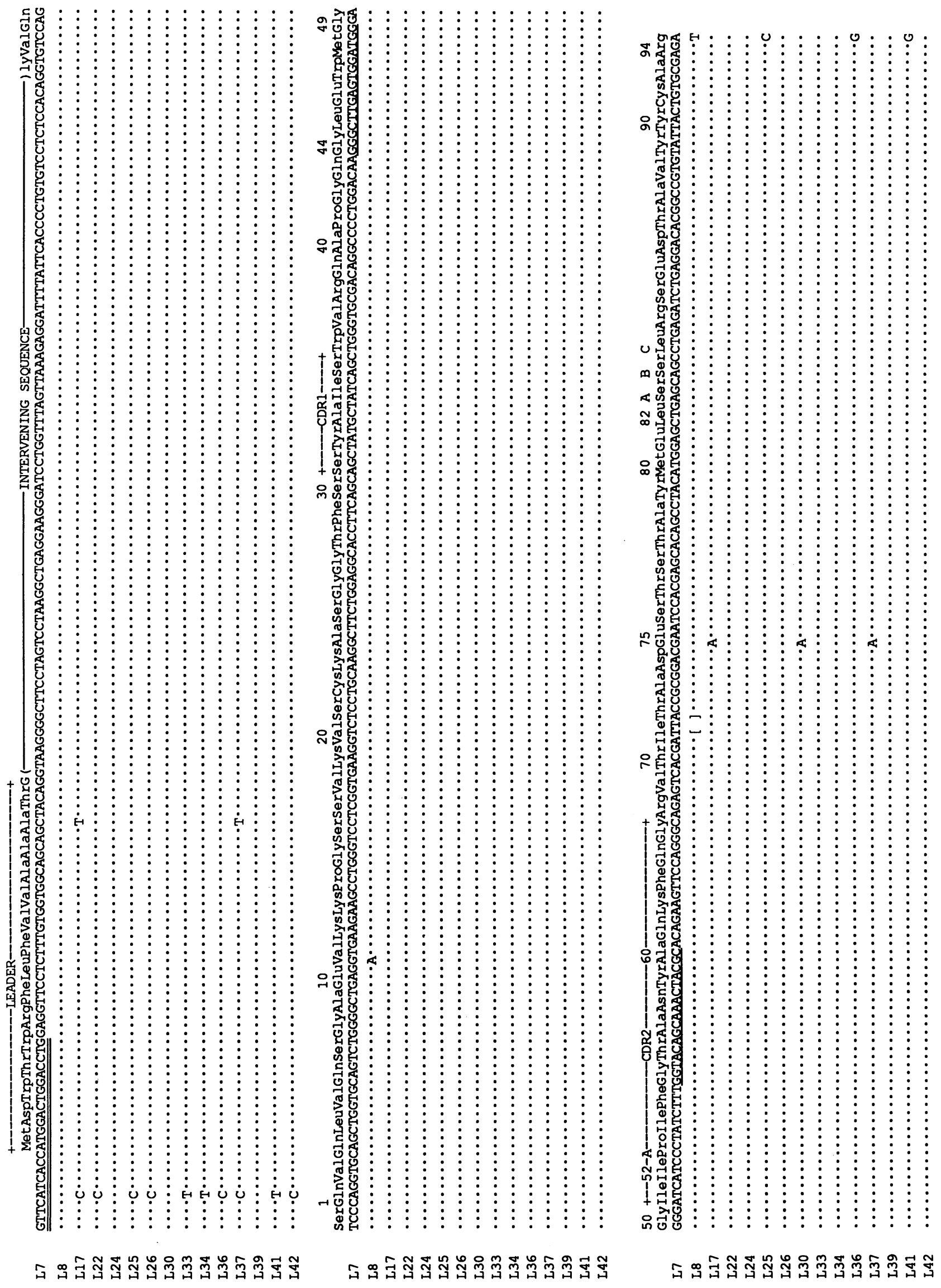

2092 T. J. Kipps and S. F. Duffy 
these cells acquired phenotypic characteristics of germinal center lymphocytes; i.e., they lost sIgD expression and became positive for CD10. However, as noted, CRI-bearing B cells that do not express CD5 have the phenotype of mantle zone lymphocytes. Thus, CD5-negative CRI-bearing B cells at least do not represent such differentiated CD5 B cells.

Alternatively, CRI-bearing B lymphocytes may constitute a $B$ cell population with characteristics of the CD5 B cell. Although used as a marker for a subpopulation of B lymphocytes, the expression of CD5 has no known relationship to the apparent physiology of the CD5 B cell, and may in fact be an epiphenomenon (reviewed in reference 45). Furthermore, B cells cannot be delineated readily into discrete subpopulations based on the detectable level of CD5 surface antigen. Enumeration of CD5 B cells requires subtraction methods, in which the percent number of isotype-control-stained B cells that have fluorescence above a certain threshold is subtracted from percent number of anti-CD5-MAb-stained cells that are detected above that same threshold. Cells with extremely low levels of CD5 may not fluoresce brightly enough to be scored as positive, even when stained with the brightest of fluorochrome-labeled antiCD5 MAbs. As such, it may be argued that all CRI-bearing B cells actually may express CD5, but at levels below detection using flow cytometric analyses.

Finally, CRI-bearing "CD5-negative" B cells may be similar to the CD5-negative "sister" population of B cells detected in the mouse (46-48). In experiments aimed at characterizing the CD5 B cell population and its progenitors in the mouse peritoneum, peritoneal B cells were found that did not express surface CD5 but apparently had other phenotypic traits peculiar to CD5 B cells (46), such as the surface expression of MAC1 (CD1 lb) (49), extended longevity in vitro, or ability to generate spontaneous oligoclonal $\mathrm{B}$ cell expansions in vivo that resemble human B cell CLL (50). In transfer experiments, such CD5-negative sister cells initially were found to reconstitute mice only whenever the adoptive hosts were reconstituted with CD5 B cells (46). More recent studies, however, suggest that such cells may constitute a related but possibly independent and self-renewing B cell subpopulation that may arise latter in ontogeny than B cells that express detectable levels of the CD5 surface antigen $(46,48)$. By analogy, CD5-negative CRI-bearing $B$ cells may be generated at a later stage of B cell development than CRI-bearing CD5 B cells, but still express many of the traits that are associated with the CD5 B cell.

One peculiar phenotypic characteristic proposed for CD5 B cells is stable Ig V gene expression with little or no somatic mutation. Independent clones of CD5 B cells may express identical $\mathrm{V}$ genes without evidence for somatic mutation (51, 52). The antibodies encoded by such $\mathrm{V}$ genes frequently are reactive with a variety of self antigens, i.e., proteolytically processed erythrocyte membranes, denatured DNA, and/or the Fc portion of self $\mathrm{IgG}$ (53-57). Stable expression of such $\mathrm{V}$ genes with little or no somatic mutation may account for the finding that CD5 B cells are enriched for cells that spontaneously produce IgM autoantibodies $(19,20)$.

In this light, it was important to examine the $\mathrm{V}$ genes expressed by CRI-bearing cells. Previous studies indicated that the G6 CRI was found on Ig heavy chains of the $V_{H} 1$ subgroup (58). In CLL, G6 reactive leukemia cells were found to express identical $V_{H} 1$ genes, indicating that the G6 CRI is a marker for one $V_{H} 1$ gene(s) expressed with little or no somatic mutation (10). However, it was not known whether this relationship is valid for nonmalignant G6-reactive B cells. Conceivably, B cells free to permute their expressed $\mathrm{V}$ genes through the process of somatic mutation may express G6-reactive Ig encoded by other $V_{H} 1$ genes or $V_{H} 1$ genes that have diversified from those present in the germline DNA. Indeed, the $V_{H} 1$ heavy chains of a few IgM autoantibodies that share only modest homology to the heavy chain expressed by G6-reactive CLL are known to react with the G6 MAb (58). Particularly in light of the finding that a large fraction of G6-reactive cells do not express detectable levels of CD5, it was important to examine the $V_{H} 1$ genes used by cells expressing the G6-CRI.

Nucleic acid sequence analyses of the $\operatorname{Ig} \mathrm{V}_{\mathrm{H}} 1$ genes rearranged and presumably expressed in G6-reactive cells revealed little evidence for somatic mutation. Other than clones $\mathrm{L} 17, \mathrm{~L} 30$, and $\mathrm{L} 34$, all other clones have $\mathrm{V}_{\mathrm{H}} 1$ genes that were identical to $\mathrm{L} 7$ (Fig. 4). The $\mathrm{V}_{\mathrm{H}}$ genes of clones L17 and L34, that apparently are derived from the same B cell clone (L17/ L34), differ from L7 at only two sites (Fig. 4). L17 and L34, moreover, share with an independent clone, L30, the same nonconservative $G \rightarrow$ A substitution in codon 74 . Conceivably the $\mathrm{L} 17 / \mathrm{L} 34$ and the $\mathrm{L} 30 \mathrm{~V}_{\mathrm{H}} 1$ genes are derived from the same allele. In this case, the common base substitution noted in these clones may represent an allelic polymorphism in the $V_{H} 1$ gene(s) encoding G6-reactive heavy chains, rather than a somatic mutation event. In any case, in over 5,600 bases evaluated for the $V_{H}$ genes of the 13 independent and functional clones, we find only three base substitutions, representing a fidelity in the DNA sequences of $>99.94 \%$. The absence of even nonconservative base changes indicates that the conserved $V_{H}$ gene sequences are not the mere consequence of selection for cells having reactivity for the G6 MAb. Rather, these data indicate that G6-reactive tonsillar B cells express homologous $V_{H} 1$ genes with little or no somatic mutations.

Even in the CDR 3 region, much of the diversity apparently is not the result of somatic mutation subsequent to Ig gene rearrangement. Except at sites flanking the $D$ region that may be generated by amino-terminal sequence insertions, threefourths of the independent clones $(11 / 15)$ have short stretches of complete homology with known germline D segments (L7, L8, L22, L24, L26, L30, L33, L34, L36, L39, L42). Also, except for codons immediately contiguous to the $\mathrm{D}-\mathrm{J}_{\mathrm{H}}$ junction, all clones that use the same $J_{H}$ gene segment have sequences

Figure 4. Nucleic acid sequence comparison of rearranged Ig $\mathrm{V}_{\mathbf{H}} 1$ genes amplified from G6-reactive tonsillar lymphocytes. The name of each sequence is listed on the left. All sequences are compared with L7. A dot $(\cdot)$ indicates homology between the compared sequences and a letter indicates a base difference. In L8, the site of the single base deletion is framed with brackets. Listed above the sequence of L7 are the amino acid position numbers according to Kabat et al. (37), and descriptions indicating the location of the leader sequence, the CDR1 and CDR2. The $5^{\prime}$ end of the leader sequence that corresponds to the PCR primer is indicated by a double underline. The sequences recognized by the oligonucleotide probes "FR2" (aa positions 44-49) and "CDR2" (aa positions 55-60) are underlined. These sequence data are available from EMBL/ GenBank/DDBJ under accession numbers M65090-M65104. 


\section{SEGMENT}

\begin{tabular}{|c|c|}
\hline L7 & $\begin{array}{l}\text { GlyGlyLysGlyIleThrMetThrSer } \\
\text { GGGGGAAAGGATTACTATGACTTCT }\end{array}$ \\
\hline Dxp'1 &  \\
\hline L8 & $\begin{array}{l}\text { LeuGlyGlyValEndGlnLeuValArgV } \\
\text { GAGGGGGAGATAGCAGCTCGTCCGCG }\end{array}$ \\
\hline DN4 & $\ldots \ldots \ldots \ldots \ldots$ \\
\hline L17 & $\begin{array}{l}\text { GlySerThrValThrThrGlyAsp } \\
\text { GGGAGTACGGTGACTACGGGAGAT }\end{array}$ \\
\hline DA1 & $T \cdot C \cdot \cdots A \cdot A \cdots \cdots$ \\
\hline L22 & $\begin{array}{l}\text { GluGlyTyrCysSerSerThrSerCysSer } \\
\text { GAGGGATATTGTAGTAGTACCAGCTGCTCG }\end{array}$ \\
\hline DLR4 & 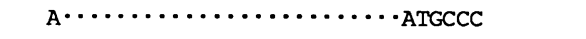 \\
\hline L24 & $\begin{array}{l}\text { GluValValGlyCysSerSerThrSerCys } \\
\text { GAGGTGGTTGTTGTAGTAGTACCAGCTGC }\end{array}$ \\
\hline DLR2 & A.GATA $\cdots \cdots \cdots \cdots \cdots \cdots \cdot$ TATGCCC \\
\hline L25 & $\begin{array}{l}\text { SerLeuArgArgTyrSerSerGl yTrpTyrGluGly } \\
\text { TCCCTCCGGCGGTATAGCAGTGGCTGGTACGAGGGT }\end{array}$ \\
\hline DN1 & $\mathrm{G} \cdots \cdots \cdots \cdot \mathrm{CA} \cdot \cdots \cdots$ \\
\hline L26 & $\begin{array}{l}\text { GlyAsp } \\
\text { GGGGAC }\end{array}$ \\
\hline
\end{tabular}

JH SEGMENT

TyrCysTyrTyrTyrGlyMetAspValTrpGlyGlnGlyThrThrValThrValserSer TACTGCTACTACTACGGTATGGACGTCTGGGGCCAAGGGACCACGGTCACCGTCTCCTCA

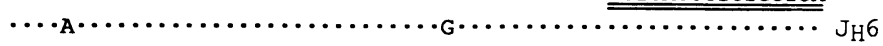
alLeuP roAlaLeuGl yP roGlyHisProGlyHisArgLeuLeu TACTTCCAGCACTGGGGCCAGGGCACCCTGGTCACCGTCTCCTCA

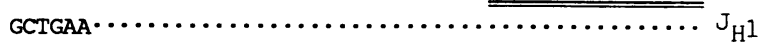

PheAspTyrTrpGlyGlnGlyThrLeuValThrValserser TTTGACTACTGGGGCCAGGGAACCCTGGTCACCGTCTCCTCA

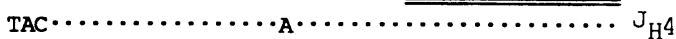

AsnTrpPheAspProTrpGlyGlnGlyThrLeuValThrValSerSer AACTGGTTCGACCCCTGGGGCCAGGGAACCCTGGTCACCGTCTCCTCA ........

TyrTyrTyrTyrGlyMetAspValTrpGlyGlnGlyThrThrValThrValSerSer TACTACTACTACGGTATGGACGTCTGGGGCCAAGGACCACGGTCACCGTCTCCTCA

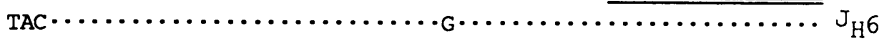

PheAspTyrTrpGlyGlnGlyThrLeuValThrValserSer TTTGACTACTGGGGCCAGGGAACCCTGGTCACCGTCTCCTCA


AsnTrpPheAspProTrpGlyGlnGlyThrLeuValThrValserSer AACTGGTTCGACCCCTGGGGCAGGGAACCCTGGTCACCGTCTCCTCA

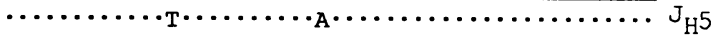

GlYArgThrArgValSerValSerThrLeuTyrAspSerSerGlyTyrTyrAspPheSerGly TyrTyrGlyMetAspValTrpglyGlnGlyThrThrValThrValSerSer GGCCGGACCCGGGTATCGGTTTCGACCCTCTATGATAGTAGTGGTTATTACGACTTCTCCGGC TACTACGGTATGGACGTCTGGGCCAAGGGACACGGTCACCGTCTCCTCA DXp1 $\quad$ TATTA $\cdot G \cdot A T \cdot T T G \cdot C \cdots \cdots \cdots \cdot$ TA $\cdots$

Gly

L33 GGA

DLR1 - . TATTGTACTGGTGGTGTATGCTATACC

GlySerSerTrpThr

GGCAGCAGCTGGACC

DN1 A........TA.

MetTyrAsnTrpAsnPhe

ATGTATAACTGGAACTTT

DM1 G.........AC

GlySerThrValThrThrGlyAsp

GGGAGTACGGTGACTACGGGAGAT

$\mathrm{T} \cdot \mathrm{C} \cdots \mathrm{A} \cdot \mathrm{A} \cdot \cdots \cdot$

AspThrSerSerGlyTyrTyrArg

L39 GATACTAGTAGTGGTTATTATCGC
Dxp4 GTATTAC $\cdots$ TT $\cdot$ T.G............

GlyGlyValAlaGlyArgProHis

L41 GGCGGAGTTGCTGGTAGGCCCCAT

DLR4 AGGATATT $\cdot \mathrm{TA} \cdot \mathrm{T} \cdot \mathrm{CCA} \cdots \mathrm{C} \cdot \mathrm{T} \cdot \cdots$

GlyGlyMetGlyTyrCysSerGlyGlySerCys GGGGGGATGGGATATTGTAGTGGTGGTAGCTGC

DLR2 A............... TACTCCC



TyrTyrTyrTyrTyrGlyMetAspValTrpGlyGlnGlyThrThrValThrValserser TACTACTACTACTACGGTATGGACGTCTGGGGCCAAGGGACCACGGTCACCGTCTCCTCA

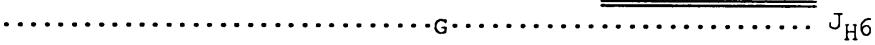

PheAspTyrTrpGlyGlnGlyThrLeuValThrValserSer TTTGACTACTGGGGCCAGGGAACCCTGGTCACCGTCTCCTC

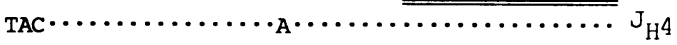

PheAspTyrTrpGlyGlnglyThrLeuValThrValserser TTTGACTACTGGGGCCAGGGAACCCTGGTCACCGTCTCCTCA

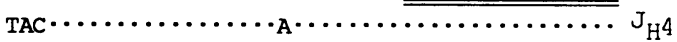

PheAspTyrTrpGlyGlnGlyThrLeuValThrValSerSer TTTGACTACTGGGGCCAGGGAACCCTGGTCACCGTCTCCTCA

LeuAspTyrTrpGlyGlnGlyThrLeuValThrValserSer CTTGACTACTGGGGCCAGGGAACCCTGGTCACCGTCTCCTCA

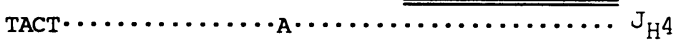

PheAspTyrTrpGlyGlnGlyThrLeuValThrValserSer TTCGACTACTGGGGCCAGGGAACCCTGGTCACCGTCTCCTCA

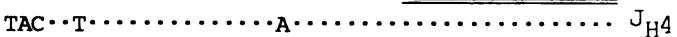

TyrTrpPheAspProTrpGlyGlnGlyThrLeuValThrValSerSer TACTGGTTCGACCCCTGGGGCCAGGGAACCCTGGTCACCGTCTCCTCA

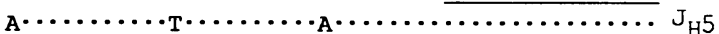

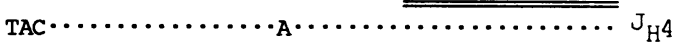

Figure 5. Deduced D and $\mathrm{J}_{\mathbf{H}}$ segments of the $\mathrm{Ig}$ heavy chain variable region sequences. Each sequence is compared to the known $\mathrm{D}$ and $\mathrm{J}_{\mathbf{H}}$ segments that have the greatest homology (37-41). Sequence comparisons are indicated as in Fig. 2. These sequence data are available from EMBL/GenBank/DDBJ under accession numbers M65090-M65104.

that differ from known germline $J_{H}$ gene segments at the same site and with the same base substitution (Fig. 5). For example, all clones with $\mathrm{J}_{\mathrm{H}} 4$ differ from published germline $\mathrm{J}_{\mathrm{H}} 4$ minigenes (59) with a $A \rightarrow G$ substitution in the sixth codon of the $\mathrm{J}_{\mathrm{H}}$ segment (Fig. 5). In addition, an $A \rightarrow G$ substitution at this same location was noted in the deduced $\mathrm{J}_{\mathrm{H}} 4$ gene segment used by G6-reactive leukemic cells (10) and 4B4, a human-human B cell hybridoma expressing a $V_{H^{4}}$ gene with little or no somatic mutation (56). It is unlikely that such substitutions would occur repeatedly in different clones that had undergone indepen- dent gene rearrangements. As such, except at sites that may be permuted during the process of Ig gene rearrangement, the differences from published $\mathrm{J}_{\mathrm{H}}$ sequence may be secondary to genetic polymorphisms, rather than to somatic mutations in the rearranged $\mathrm{J}_{\mathrm{H}}$ gene segment.

It is unlikely that the methods used in this study skewed our analyses to favor isolation of rearranged $\mathrm{V}$ genes that not undergone somatic mutation. We used primers corresponding to consensus sequences common to all $\mathrm{J}_{\mathrm{H}}$ gene segments and to a sequence at the $5^{\prime}$ region of all $V_{H} 1$ leader sequences. Conceiv- 
ably, chance mutations in a rearranged $V_{H} 1$ gene at the sites recognized by these primers may disrupt the ability of that $V_{H} 1$ gene to be amplified by our methods. However, these same primers have successfully amplified $V_{H} 1$ genes other than those found in this study, including $V_{H} 1$ genes that have undergone apparent somatic mutation subsequent to $\mathrm{V}$ gene rearrangement. (T.J. Kipps, R. Kobayashi, and S. Duffy, unpublished observations). Also, the amount of $\mathrm{V}_{\mathrm{H}} 1$ gene product produced in PCR of G6-reactive tonsillar lymphocytes is comparable to that produced in PCR of G6-reactive leukemia cell DNA. Thus, it seems unlikely that the bias introduced by our methods could account for the results that we obtained in this study. Rather, a more likely explanation is that G6-reactive tonsillar $B$ cells express homologous $V_{H} 1$ genes with little or no somatic mutations.

Consistent with this interpretation is our finding that some of the tonsils tested did not have any cells reactive with G6. If the G6 MAb could bind to heavy chains encoded by several different $V_{H} 1$ genes, then finding persons without any G6-positive cells would be unlikely. That over $10 \%$ of the tonsils examined did not have any cells reactive with the G6 MAb, indicates that a fairly high proportion of the population may lack expression of any $V_{H}$ genes that can encode Ig heavy chains with this major CRI. Considering the conservation noted in the $V_{H} 1$ gene sequences of G6-reactive cells ([10] and this study), the frequent expression of the $V_{H} 1$ gene(s) encoding the G6-CRI the fetal immune repertoire $(18,60)$, the association of the G6-CRI with IgM autoantibodies $(5,61)$, and relative high-frequency expression of this CRI in CLL and $\operatorname{SLL}(4,6)$, the absence of $\mathrm{G} 6$ expression may reflect a polymorphism in $\mathrm{V}_{\mathrm{H}} 1$ gene use that possibly has physiologic significance.

Finally, these studies indicate that a relatively high proportion of mantel zone lymphocytes expresses autoantibody-associated CRIs. sIgD-bearing cells constitute only a fraction of the total B cells, ranging from $37 \%$ to $87 \%$ of the CD19-positive cells (Table I). As noted, the 17.109 CRI and/or the G6 CRI predominantly is expressed by cells that co-express sIgD. Since such sIgD bearing cells predominantly represent mantle zone lymphocytes, the 17.109-reactive, or G6-reactive cells, respectively, may constitute $4-17 \%$ and $0-12 \%$ of the mantle zone lymphocytes. These frequencies approach those noted for CRI expression in CLL. Conceivably transformation of lymphocytes such as those found in the mantel zone may account for the high frequency expression of autoantibody-associated CRIs in CLL and related malignancies. However, there is an apparent bias for co-expression of both 17.109 and G6 by leukemia cell populations that is not noted in most tonsillar lymphocyte populations studied. Biased co-expression of the 17.109 CRI and the G6 CRI by leukemia cell populations may reflect selection of CRI-bearing cells based upon the binding activities of the expressed Ig. Further comparative analyses of the immunoglobulins produced by malignant and normal B cells may help resolve whether neoplastic CRI-bearing cells arise from a subset of normal CRI-bearing B lymphocytes.

\section{Acknowledgments}

We thank Drs. Rizgar Mageed and Roy Jefferis (University of Birmingham, Birmingham, England) for the G6 MAb and Dr. George Abraham (University of Rochester, Rochester, NY) for the anti$\mathrm{V}_{\mathrm{H}}$ IIIb MAb. We thank Dr. Dennis A. Carson (University of California, San Diego) for his careful reading of this manuscript and helpful advice. In addition, we acknowledge the fine technical assistance of Mr. Grant Meisenholder.

Dr. Kipps is a Scholar of the Leukemia Society of America, funded in part by the Scott Helping Hand Fund. This work was supported in part by National Institutes of Health grants AR38475 and AG04100.

\section{References}

1. Kipps, T. J., S. Fong, E. Tomhave, P. P. Chen, R. D. Goldfien, and D. A. Carson. 1987. High-frequency expression of a conserved kappa light-chain variable-region gene in chronic lymphocytic leukemia. Proc. Natl. Acad. Sci. USA. 84:2916-2920.

2. Carson, D. A and S. Fong 1983. A common idiotope on human rheumatoid factors identified by a hybridoma antibody. Mol. Immunol. 20:1081-1087.

3. Carson, D. A., P. P. Chen, T. J. Kipps, V. Radoux, F. R. Jirik, R. D. Goldfien, R. I. Fox, G. J. Silverman, and S. Fong. 1987. Idiotypic and genetic studies of human rheumatoid factors. Arthritis Rheum. 30:1321-1325.

4. Kipps, T. J., B. A. Robbins, P. Kuster, and D. A. Carson. 1988. Autoantibody-associated cross-reactive idiotypes expressed at high frequency in chronic lymphocytic leukemia relative to B-cell lymphomas of follicular center cell origin. Blood. 72:422-428.

5. Mageed, R. A., M. Dearlove, D. M. Goodall, and R. Jefferis. 1986. Immunogenic and antigenic epitopes of immunoglobulins. XVII. Monoclonal antibodies reactive with common and restricted idiotopes to the heavy chain of human rheumatoid factors. Rheumatol. Int. 6:179-183.

6. Kipps, T. J. B. A. Robbins, A. Tefferi, G. Meisenholder, P. M. Banks, and D. A. Carson. 1990. CD5-positive B-cell malignancies frequently express crossreactive idiotypes associated with IgM autoantibodies. Am. J. Pathol. 136:809816.

7. Kipps, T. J., E. Tomhave, P. P. Chen, and D. A. Carson. 1988. Autoantibody-associated kappa light chain variable region gene expressed in chronic lymphocytic leukemia with little or no somatic mutation. Implications for etiology and immunotherapy. J. Exp. Med. 167:840-852.

8. Pratt, L. F., L. Rassenti, J. Larrick, B. Robbins, P. Banks, and T. J. Kipps. 1989. Immunoglobulin gene expression in small lymphocytic lymphoma with little or no somatic hypermutation. J. Immunol. 143:699-705.

9. Radoux, V., P. P. Chen, J. A. Sorge, and D. A. Carson. 1986. A conserved human germline $\mathrm{V}$ kappa gene directly encodes rheumatoid factor light chains. $J$. Exp. Med. 164:2119-2124.

10. Kipps, T. J., E. Tomhave, L. F. Pratt, S. Duffy, P. P. Chen, and D. A. Carson. 1989. Developmentally restricted VH gene expressed at high frequency in chronic lymphocytic leukemia. Proc. Natl. Acad. Sci. USA. 86:5913-5917.

11. Caligaris-Cappio, F., M. Gobbi, M. Bofill, and G. Janossy. 1982. Infrequent normal B lymphocytes express features of B-chronic lymphocytic leukemia. J. Exp. Med. 155:623-628.

12. Gobbi, M., F. Caligaris-Cappio, and G. Janossy. 1983. Normal equivalent cells of B cell malignancies: analysis with monoclonal antibodies. Br. J. Haematol. 54:393-403.

13. Gadol, N., and K. A. Ault. 1986. Phenotypic and functional characterization of human Leul (CD5) cells. Immunol. Rev. 93:23-34.

14. Hardy, R. R., and K. Hayakawa. 1986. Development and physiology of Ly-1 B and its human homolog, Leu-1 B. Immunol. Rev. 93:53-79.

15. Kipps, T. J., and J. H. Vaughan. 1987. Genetic influence on the levels of circulating CDS B lymphocytes. J. Immunol. 139:1060-1064.

16. Bofill, M., G. Janossy, M. Janossa, G. D. Burford, G. J. Seymour, P. Wernet, and E. Kelemen. 1985. Human B cell development. II. Subpopulations in the human fetus. J. Immunol. 134:1531-1538.

17. Antin, J. H., S. G. Emerson, P. Martin, N. Gadol, and K. A. Ault. 1986. Leu-1 + (CD5+) B cells: a major lymphoid subpopulation in fetal spleen. Phenotypic and functional studies. J. Immunol. 136:505-510.

18. Kipps, T. J., B. A. Robbins, and D. A. Carson. 1990. Uniform high frequency expression of autoantibody-associated cross-reactive idiotypes in the primary B cell follicles of human fetal spleen. J. Exp. Med. 171:189-196.

19. Casali, P., S. E. Burastero, M. Nakamura, G. Inghirami, and A. L. Notkins. 1987. Human lymphocytes making rheumatoid factor and antibody to belong to Leu-1+ B-cell subset. Science (Wash. DC). 236:77-81.

20. Hardy, R. R., K. Hayakawa, M. Shimizu, K. Yamasaki, and T. Kishimoto. 1987. Rheumatoid factor secretion from human Leu-1+ B cells. Science (Wash. DC). 236:81-83.

21. Carson, D. A. P. P. Chen, T. J. Kipps, V. Radoux, F. Jirik, R. D. Goldfien, R. I. Fox, G. J. Silverman, and S. Fong. 1987. Molecular basis for the cross-reactive idiotypes on human anti-IgG autoantibodies (rheumatoid factors). Ciba Found. Symp. 129:123-134.

22. Silverman, G. J., R. D. Goldfien, P. Chen, R. A. Mageed, R. Jefferis, F. Goni, B. Frangione, S. Fong, and D. A. Carson. 1988. Idiotypic and subgroup analysis of human monoclonal rheumatoid factors: implications for structural and genetic basis of autoantibodies in humans. J. Clin. Invest. 82:469-475.

23. Robbins, B. A. 1987. Diagnostic immunohistochemistry of lymphoma 
and related disorders: practical aspects of frozen section technique and interpretation. J. Clin. Lab. Anal. 1:104-115.

24. Greenstein, J. L., A. Solomon, and G. N. Abraham. 1984. Monoclonal antibodies reactive with idiotypic and variable-region specific determinants on human immunoglobulins. Immunology. 51:17-25.

25. Reinherz, E. L., R. E. Hussey, and S. F. Schlossman. 1980. A monoclonal antibody blocking human T cell function. Eur. J. Immunol. 10:758-762.

26. Maruyama, S., H. Kubagawa, and M. D. Cooper. 1985. Activation of human B cells and inhibition of their terminal differentiation by monoclonal anti-mu antibodies. J. Immunol. 135:192-199.

27. Kubagawa, H., W. E. Gathings, D. Levitt, J. F. Kearney, and M. D. Cooper. 1982. Immunoglobulin isotype expression of normal pre-B cells as determined by immunofluorescence. J. Clin. Immunol. 2:264-269.

28. Tedder, T. F., L. T. Clement, and M. D. Cooper. 1984. Expression of C3d receptors during human $\mathrm{B}$ cell differentiation: Immunofluorescence analysis with the HB-5 monoclonal antibody. J. Immunol. 133:678-683.

29. Fox, R. I., D. Harlow, I. Royston, and J. Elder. 1982. Structural characterization of the human T cell surface antigen (p67) isolated from normal and neoplastic lymphocytes. J. Immunol. 129:401-405.

30. Parks, D. R., L. L. Lanier, and L. A. Herzenberg. 1986. Flow cytometry and fluorescence activated cell sorting (FACS). In Handbook of Experimental Immunology. D. M. Weir, L. A. Herzenberg, and C. Blackwell, editors. Blackwell Scientific Publications, Oxford. 29.1-29.21.

31. Saiki, R. K., D. H. Gelfand, S. Stoffel, S. J. Scharf, R. Higuchi, G. T. Horn, K. B. Mullis, and H. A. Erlich. 1988. Primer-directed enzymatic amplification of DNA with a thermostable DNA polymerase. Science (Wash. DC). 239:487-491.

32. Hattori, M., and Y. Sakaki. 1986. Dideoxy sequencing method using denatured plasmid templates. Anal. Biochem. 152:232-238.

33. Hsu, S.-M., and E. S. Jaffe. 1984. Phenotypic expression of B-lymphocytes. 2. Immunoglobulin expression of germial center cells. Am. J. Pathol. 114:396-402

34. Gadol, N., M. A. Peacock, and K. A. Ault. 1988. Antigenic phenotype and functional characterization of human tonsil B cells. Blood. 71:1048-1055.

35. Weinberg, D. S., K. A. Ault, M. Gurley, and G. S. Pinkus. 1986. The human lymph node germinal center cell: characterization and isolation by using two-color flow cytometry. J. Immunol. 137:1486-1494.

36. Newkirk, M. M., H. Gram, G. F. Heinrich, L. Ostber g, J. D. Capra, and R. L. Wasserman. 1988. Complete protein sequences of the variable regions of the cloned heavy and light chains of a human anticytomegalovirus antibody reveal a striking similarity to human monoclonal rheumatoid factors of the Wa idiotypic family. J. Clin. Invest. 81:1511-1518.

37. Kabat, E., T. T. Wu, M. Reid-Miller, H. M. Perry, and K. S. Gottesmann 1987. Sequences of Proteins of Immunological Interest. Publication No. 1987:165-462. U.S. Government Printing Office, Bethesda, MD.

38. Siebenlist, U., J. V. Ravetch, S. Korsmeyer, T. Waldmann, and P. Leder. 1981. Human immunoglobulin D segments encoded in tandem multigenic families. Nature (Lond.). 294:631-635.

39. Ichihara, Y., M. Abe, H. Yasui, H. Matsuoka, and Y. Kurosawa. 1988. At least five DH genes of human immunoglobulin heavy chains are encoded in 9-kilobase DNA fragments. Eur. J. Immunol. 18:649-652.

40. Ichihara, Y., H. Matsuoka, and Y. Kurosawa. 1988. Organization of human immunoglobulin heavy chain diversity gene loci. EMBO (Eur. Mol. Biol. Organ.) J. 7:4141-4150.

41. Matsuda, F., K. H. Lee, S. Nakai, T. Sato, M. Kodaira, S. Q. Zong, H. Ohno, S. Fukuhara, and T. Honjo. 1989. Dispersed localization of D segments in the human immunoglobulin heavy-chain locus. EMBO (Eur. Mol. Biol. Organ.) J. 7:1047-1051.

42. Yancopoulos, G. D., and F. W. Alt. 1986. Regulation of the assembly and expression of variable-region genes. Annu. Rev. Immunol. 4:339-368.

43. Desiderio, S. V., G. D. Yancopoulos, M. Paskind, E. Thomas, M. A. Boss,
N. Landau, F. W. Alt, and D. Baltimore. 1984. Insertion of N regions into heavychain genes is correlated with expression of terminal deoxytransferase in B cells. Nature (Lond.). 311:752-755.

44. Caligaris-Cappio, F., M. Riva, L. Tesio, M. Schena, G. Gaidano, and L. Bergui. 1989. Human normal CD5+ B lymphocytes can be induced to differentiate to CD5- B lymphocytes with germinal center cell features. Blood. 73:12591263.

45. Kipps, T. J. 1989. The CD5 B cell. Adv. Immunol. 47:117-185. 46. Herzenberg, L. A., A. M. Stall, P. A. Lalor, C. Sidman, W. A. Moore, and D. R. Parks. 1986. The Ly-1 B cell lineage. Immunol. Rev. 93:81-102.

47. Herzenberg, L. A., and A. M. Stall. 1989. Conventional and Ly-1 B-cell lineages in normal and mu transgenic mice. Cold Spring Harbor Symp. Quant. Biol. 54:219-225.

48. Herzenberg, L. A., and L. A. Herzenberg. 1989. Toward a layered immune system. Cell. 59:953-954.

49. Herzenberg, L. A., A. M. Stall, J. Braun, D. Weaver, D. Baltimore, and R. Grosschedl. 1987. Depletion of the predominant B-cell population in mu heavychain transgenic mice. Nature (Lond.). 329:71-73.

50. Stall, A. M., M. C. Farinas, D. M. Tarlinton, P. A. Lalor, L. A. Herzenberg, and S. Strober. 1988. Ly-1 B-cell clones similar to human chronic lymphocytic leukemia routinely develop in older normal mice and young autoimmune Zealand Black-related animals. Proc. Natl. Acad. Sci. USA. 85:7312-7316.

51. Forster, I., H. Gu, and K. Rajewsky. 1988. Germline antibody V regions as determinants of clonal persistence and malignant growth in the B cell compartment. EMBO (Eur. Mol. Biol. Organ.) J. 7:3693-3703.

52. Tarlinton, D., A. M. Stall, and L. A. Herzenberg. 1988. Repetitive usage of immunoglobulin VH and D gene segments in CD5+ Ly-1 B clones of (NZB $\times$ NZW)F1 mice. EMBO (Eur. Mol. Biol. Organ.) J. 7:3705-10.

53. Reininger, L., P. Ollier, P. Poncet, A. Kaushik, and J. C. Jaton. 1987. Novel $\mathrm{V}$ genes encode virtually identical variable regions of six murine monoclonal anti-bromelain-treated red blood cell autoantibodies. J. Immunol. 138:316323.

54. Sanz, I., P. Casali, J. W. Thomas, A. L. Notkins, and J. D. Capra. 1989. Nucleotide sequences of eight human natural autoantibody $\mathrm{VH}$ regions reveals apparent restricted use of VH families. J. Immunol. 142:4054-4061.

55. Nakamura, M., S. E. Burastero, Y. Ueki, J. W. Larrick, A. L. Notkins, and P. Casali. 1988. Probing the normal and autoimmune B cell repertoire with Epstein-Barr virus: frequency of B cells producing monoreactive high affinity autoantibodies in patients with Hashimoto's disease and systemic lupus erythematosus. J. Immunol. 141:4165-4172.

56. Sanz, I., H. Dang, M. Takei, N. Talal, and J. D. Capra. 1989. VH sequence of a human anti-Sm autoantibody. Evidence that autoantibodies can be unmutated copies of germline genes. J. Immunol. 142:883-887.

57. Baccala, R., T. V. Quang, M. Gilbert, T. Ternynck, and S. Avrameas. 1989. Two murine natural polyreactive autoantibodies are encoded by nonmutated germ-line genes. Proc. Natl. Acad. Sci. USA. 86:4624-4628.

58. Newkirk, M. M., R. A. Mageed, R. Jefferis, P. P. Chen, and J. D. Capra. 1987. Complete amino acid sequences of variable regions of two human IgM rheumatoid factors, BOR and KAS of the Wa idiotypic family, reveal restricted use of heavy and light chain variable and joining region gene segments. J. Exp. Med. 166:550-564.

59. Ravetch, J. V., U. Siebenlist, S. Korsmeyer, T. Waldmann, and P. Leder. 1981. Structure of the human immunoglobulin mu locus: characterization of embryonic and rearranged $\mathrm{J}$ and $\mathrm{D}$ genes. Cell. 27:583-591.

60. Schroeder, H. W. Jr., J. L. Hillson, and R. M. Perlmutter, 1987. Early restriction of the human antibody repertoire. Science (Wash. DC). 238:791-793.

61. Shokri, F., R. A. Mageed, E. Tunn, P. A. Bacon, and R. Jefferis. 1990. Qualitative and quantitative expression of $\mathrm{VHI}$ associated cross reactive idiotopes within IgM rheumatoid factor from patients with early synovitis. Ann. Rheum. Dis. 49:150-154. 